Published by LPMP Imperium

Journal homepage: https://ejournal.imperiuminstitute.org/index.php/JMSAB

\section{Job insecurity dan konsekuensinya pada kecemasan karyawan di saat pandemi COVID-19: peran God locus of control}

\section{Achmadi}

Sekolah Tinggi Ilmu Ekonomi Tunas Nusantara, Jakarta

\begin{abstract}
The purpose of this study was to examine the relationship between job insecurity and employee anxiety while at the same time identifying coping strategies that could withstand the adverse effects of job insecurity by placing a God locus of control (GLC). A total of 132 employees from several companies were involved in this study. This study shows that Job insecurity positively affects employee anxiety levels. God's locus of control negatively affects anxiety and acts as a boundary condition to reduce the effect of job insecurity on employee anxiety. The analysis results provide knowledge relevant to the scientific literature related to the study of job insecurity and practical implications for reducing the effect of this phenomenon on employee anxiety levels amid the COVID-19 pandemic.
\end{abstract}

\begin{abstract}
Abstrak
Tujuan dari penelitian ini adalah menguji hubungan job insecurity dengan kecemasan karyawan sekaligus mengidentifikasi strategi koping yang mampu menahan efek negative job insecurity dengan menempatkan God locus of control (GLC). Sebanyak 132 orang karyawan dari beberapa perusahaan terlibat dalam studi ini. Menggubakan makro Process, penelitian ini menunjukkan bahwa ketidakamanan kerja memiliki pengaruh positif terhadap tingkat kecemasan karyawan. Lokus kendali Tuhan memiliki efek negative terhadap kecemasan dan juga bertindak sebagai kondisi batas untuk mengurangi efek ketidakamanan kerja terhadap kecemasan karyawan. Hasilnya analisis memberikan pengetahuan yang relevan dengan literatur ilmiah yang terkait dengan studi ketidakamanan kerja, serta implikasi praktis untuk mengurangi efek fenomena ini pada tingkat kecemasan karyawan di tengah situasi pandemic COVID-19.
\end{abstract}

*Email korespondensi: achmadi@stietn.ac.id

Pedoman Achmadi, A. (2020). Job insecurity dan konsekuensinya pada kecemasan karyawan di saat pandemi COVID-19: peran God locus of control. Jurnal Manajemen Strategi Dan Aplikasi Bisnis, 3(2), 161 - 170. https://doi.org/10.36407/jmsab.v3i2.222
JMSAB 161

Paper type

Researh Paper

Keywords: job insecurity, anxiety, God locus of control

Received: 22 Oct 2021

Revised: 27 Nov 2021

Accepted: 05 Dec 2020

Online: 20 Dec 2020

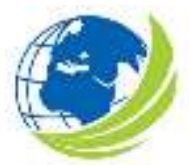

Jurnal Manajemen Strategi dan Aplikasi Bisnis, Vol 3, No.2, 2020, pp. $161-170$ eISSN 2655-237X 


\section{PENDAHULUAN}

Sampai dengan akhir 2020, dunia masih berperang dengan COVID-19. Sejak pertama kali dipublikasikan oleh WHO sebagai pandemic di awal tahun 2020, banyak Negara yang masih berjuang untuk keluar dari penularan massif virus ini, termasuk Negara-negara di Eropa dan Amerika. Tidak bisa dipungkiri bahwa kerusakan yang ditimbulkan dari pandemic ini telah menyentuh semua aspek including ekonomi, pendidikan, bahkan perilaku social masyarakat secara umum. Perubahan tatanan ekonomi akibat gagalnya aktivitas bisnis di berbagai sector kemudian menciptakan berbagai penyesuaian, termasuk penurunan jam kerja, penghasilan, bahkan pemberhentian kerja. ILO dalam laporan tahun 2020 mencatat bahwa ada lebih dari dua ratus juta orang tenaga kerja di seluruh dunia yang secara langsung terdampak akibat pengurangan jam kerja dan hilangnya penghasilan (Wilson et al., 2020). Kondisi ini mencipatkan kekhawatiran di kalangan pekerja yang dapat memicu berbagai konsekuensi negative nya ke kecemasan dan depresi karyawan.

Job insecurity adalah bagaimna sikap karyawan dalam menganggapi keamanan kerja mereka, dan konsep ini mulai diperkenalkan sejak tahun 1980-an. Isu ini telah menjadi pusat perhatian peneliti terkait dengan perubahan kualitas pekerjaan dan berbagai ancaman yang muncul dari pekerjaan tersebut. Job insecurity terus menjadi perhatian peneliti akibat globalisasi dan fleksibilitas kerja yang menjadikan semakin ketatnya persaingan di masa sekarang. Beberapa peneliti menyebutkan bahwa ada pertumbuhan yang tinggi pada ketidakamanan kerja structural sebagai akibat kontrak jangka pendek yang diberlakukan oleh perusahaan (dalam Gallie et al., 2018). Lebih lanjut, situasi pandemic sekarang diperparah dengan pembatasan social dan penutupan tempat-tempat usaha dan bisnis yang menyebabkan berbagai aktivitas terhenti. Konsekuensinya, banyak karyawan yang mengalami pemutusan kerja, pengurangan jam, dan pengurangan penghasilan.

Kondisi ketidakamanan ini merupakan pengalaman stres yang terkait dengan perasaan negatif (Ashford \& Lee, 1989). Meski demikian, masih relative sedikit penelitian telah meneliti kemungkinan implikasi psikologis dari ketidakamanan kerja selama pandemi, mengingat situasi sekarang ini merupakan sebuah situasi yang tidak disangka-sangka dan diluar dugaan. Job insecurity merupakan salah predictor kecemasan dan depresi (Cheng et al., 2019; Gallie et al., 2017; Wang et al., 2018), menurunkan kinerja (Darvishmotevali et al., 2017), komitmen (Wang et al., 2018), kesehatan mental (Llosa et al., 2018). Meskipun sudah banyak dteliti sebagai sumber stress potensional, termausk depresi dan kecemasan karyawan, masih ada hal yang kurang mendapat perhatian yang akan ditutupi oleh penelitian ini. Secara khusus, penelitian ini menempatkan God locus of control (GLC) sebagai pemoderasi hubungan job insecurity terhadap tingkat kecemasan. Dengan demikian, hasil penelitian ini dapat memberikan perpektif berbeda mengenai pengaruh job insecurity terhadap kecemasan dengan menempatkan GLC sebagai kondisi batas. Untuk tujuan ini, pendekatan strategi coping digunakan dalam menjelaskan keterkaitan antara GLC, job insecurity dan kecemasan. Tujuan akhir dari penelitian ini adalah untuk memperluas wawasan tentang peran moderasi yang dimainkan oleh GLC khusus dalam hal hubungan antara ketidakamanan kerja dan kecemasan karyawan di masa pandemi COVID19 di Indonesia.

\section{KAJIAN PUSTAKA}

Job insecurity mengacu pada persepsi individu tentang apakah mereka dapat terus mempertahankan pekerjaan mereka saat ini atau tidak (Cheung et al., 2019). Ada banyak sumber yang menyebabkan perasaan tidak aman karyawan pada pekerjaan mereka, namun secara umum penilaian ini lebih didasarkan penilaian subjektf akibat kondisi objektif yang terjadi di perusahaan 
seperti isu pemutusan hubungan kerja, perampingan organisasi, dan permasalahan lain seperti kontrak kerja (Ashford et al., 1989; Wang \& Heyes, 2017). Namun di luar itu, muncul juga ketidakmanan kerja yang sering diabaikan dalam studi sebelumnya, misalnya hilangnya berbagai komponen penting dari pekerjaan, misalnya tunjangan kinerja dan peluang promosi. Dengan demikian, job insecurity dapat dipahami sebagai persepsi subjektif yang memberikan kesimpulan yang berbeda antara satu orang dengan lainnya.

Penelitian ini mengadopsi model permintaan-sumber daya pekerjaan atai JD-R model (Bakker \& Demerouti, 2007) dan konservasi sumber daya (model COR; Hobfoll et al, 1990) untuk menjjelaskan huungan antara job insecurity dan kecemasan. Mengacu pada JD-R Model, job insecurity merupakan bentuk job resources yang dapat mengarah pada peningkatan kecemasan kerja, dan pada akhirnya dapat mempengaruhi berbagai bentuk outcome seperti kinerja, OCB, kepuasan dan lainnya. Sementara, model COR memberikan penjelasan mengenai ketidakamanan kerja sebagai stresor kerja yang menguras sumber daya karyawan. Untuk mengurangi pengurasan sumber daya, karyawan menarik diri dari pekerjaan mereka (misalnya, perilaku penarikan diri yang tinggi) atau menahan dampak negatif dengan menguras sumber daya pribadi lainnya (misalnya, mencari dukungan sosial) (Cheung et al., 2019).

Meskipun berbagai studi studi sudah mendukung penggunakan JD-R model dan COR Theory sebagai kerangka acuan untuk menjelaskan hubungan job insecurity dan kecemassan, namun kerangka kerja ini tidak secara eksplisit memberikan penjelasan factor internal seperti God locus of control. Untuk mengatasi masalah ini, kami mengadopsi strategi koping dari teori Lazarus dan Folkman. Strategi koping merupakan "upaya kognitif dan perilaku yang terus berubah yang diterapkan untuk mengelola tuntutan internal dan eksternal tertentu yang dinilai melebihi sumber daya orang tersebut" (Lazarus dan Folkman, 1984, 141). Koping juga dapat dinyatakan sebagai upaya untuk mengurangi efek negative stress pada kesehatan mental seseorang, dan oleh karenanya, sikap ini bersifat personal. Dapat dinyatakan bahwa sebuah situasi dapat dinilai berbeda apakah sebagai sumber stress atau tidak berdasarkan pertimbangan individual (Lazarus dan Folkman, 1984). Studi ini menempatkan GLC sebagai positive religious coping behavior (Pargament et al., 2011) yang dapat menetralisir atau mebgurangi efek negatif pada situasi stres pada individu.

\section{Job insecurity dan kecemasan}

Job insecurity mengacu pada persepsi subjektif karyawan tentang kehilangan pekerjaan mereka karena adanya perubahan termasuk organisasi yang sebenarnya (misalnya perampingan, pengurangan karyawan), perubahan organisasi yang dikabarkan (sekedar isu mengenai pengurangan karyawan), atau penurunan ekonomi (Ashford et al., 1989; Schreurs et al., 2016). Dalam konteks ini, job insecurity disebabkan karena situasi COVID-19 yang menyebabkan terjadi penurunan pada aktivitas bisnis sehingga banyak perusahaan mengambil kebijakan pengurangan jam kerja atau bahkan melakukan merumahkan karyawan. Situasi tersebut dapat menyebabkan individu yang khawatir tentang kehilangan pekerjaan mereka mungkin mengalami ketegangan mental karena mereka berada dalam posisi yang tidak berdaya (Burgard, et al. 2012). Secara teeoritis dan empiris, job insecurity telah diyakini sebagai sumber ketegangan karyawan (Cheung et al., 2018; Wang et al., 2019; Wilson et al., 2020). Mengingat hubungan antara job insecurity dan kecemasan karyawan merupakan hubungan yang sudah banyak diteliti dan memperoleh pembuktikan empiris, maka hipotesis yang diajukan adalah:

H1. Job insecurity secara positif mempengaruhi kecemasan karyawan 


\section{Peran God locus of control sebagai pemoderasi}

Konsep God locus of control (GLC) merupakan bagian dari konsep locus of control (LOC). GLC pertama kali diperkenalkan oleh Welton et al. (1996) yang secara spefisik memusatkan perhatian pada tingkat kepercayaan individu atas kontrol Tuhan atas seluruh kejadian yang berlaku untuk mereka. GLC merupakan konsep yang banyak mendapatkan pertentangan terkait posisinya sebagai sumber internal atau eksternal dalam diri individu. Kelompok pertama menyatakan bahwa God locus of control dikaitkan dengan eksternal locus dipelopori oleh Welton et al (1996), dan studi terbaru lebih banyak mendukung argumen tersebut. Kelompok kedua menyatakan bahwa God locus of control lebih erat terkait dengan internal control sehingga ia memiliki konsekuensi pada peningkatan penghargaan diri, motivasi (Boyd \& Wilcox, 2020).

Studi ini menempatkan GLC sebagai pemoderasi hubungan job insecurity dengan kecemasan karyawan. Mengadopsi pendekatan strategi koping, GLC dapat bertindak sebagai perilaku koping religius yang positif (Pargament et al., 2011) yang dapat menetralisir berbagai efek merusak dari situasi atau kejadian yang kurang menguntungkan. Para peneliti percaya bahwa agama memiliki efek positif pada kemampuan individu untuk mengatasi stresor (misalnya, kesehatan yang buruk atau stres kehidupan, Schmuck 2000; Smith et al. 2000); di sisi lain, agama dapat memoderasi efek buruk dari peristiwa ini (Bradshaw dan Ellison 2010) seperti berkurangnya depresi (Brewer et al., 2014; Simoni dan Ortiz 2003). Oleh karena itu, kami memposisikan locus of control Tuhan sebagai perilaku koping religius yang positif (Pargament et al., 2011) memiliki peran dalam mengurangi efek buruk job insecurity pada tingkat kecemasan karyawan pandemi COViD-19.

H2. God locus of control secara negatif mempengaruhi kecemasan karyawan

H3. God locus of control memoderasi hubungan job insecurity terhadap kecemasan karyawan

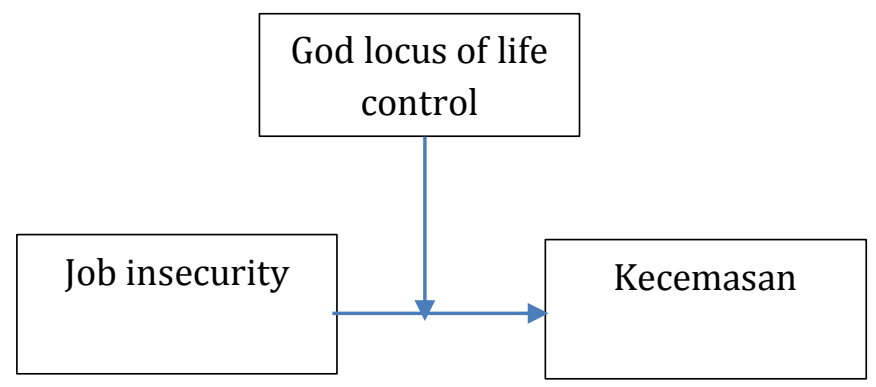

\section{Gambar 1.}

\section{Model Penelitian}

\section{METODE}

\section{Prosedur Sampel}

Penelitian ini menggunakan purposive sampling untuk menyeleksi partisipan dari berbagai perusahaan melalui jaringan alumni salah satu perguruan tinggi swasta di Jakarta. Data untuk penelitian ini dikumpulkan melalui metode survei online. Responden diberitahu tentang tujuan survei, sifat sukarela dari partisipasi, dan prosedur untuk mengisi kuesioner online. Sebanyak 151 karyawan berpartisipasi dalam studi ini, namun selah 11 jawaban di eliminasi karena duplikasi dan ketidaklengkapan maka total 132 responden digunakan sebagai data final. Tabel 1 
menampilan data mengenai karakteristik responden. Mayoritas responden adalah wanita (72.73 persen), dan separuh masih berstatus menikah (53.03 persen). Berdasarkan usia, responden didominasi oleh karyawan yang berusia 25 - 40 tahun (60.61 persen).

Tabel 1.

Karakteristik responden

\begin{tabular}{crr}
\hline & Frekuensi & Persen \\
\hline Jenis Kelamin & & \\
Laki-laki & 36 & 27.27 \\
Wanita & 96 & 72.73 \\
& & \\
Status Pernikahan & & \\
Single & 62 & 46.97 \\
Menikah & 70 & 53.03 \\
& & \\
Usia & & \\
& & \\
< 25 yo & 40 & 30.30 \\
$25-30$ yo & 32 & 24.24 \\
$31-40$ yo & 48 & 36.36 \\
$>41$ yo & 12 & 9.09 \\
\hline
\end{tabular}

Sumber: data lapangan (2021)

\section{Pengukuran}

Seluruh item di rating menggunakan skala Likert 5 poin yaitu $1=$ tidak pernah $-5=$ selalu. Ketidakamanan pekerjaan diukur dengan skala empat item dari skala De Witte dan Schreurs et al. (De Witte et al., 2000; Schreurs et al., 2010). Contoh itemnya adalah, "Saya pikir saya akan kehilangan pekerjaan dalam waktu dekat". Cronbach alpha untuk skala ini adalah 0.94 . Kecemasan karyawan diukur dengan mengadaptasi sub skala Depression Anxiety Stress Scales-21 (DASS-21) pada komponen kecemasan (anxiety). Sebanyak tujuh item digunakan dengan contoh item "Seberapa sering Anda merasa lelah tanpa alasan yang jelas?". Cronbach alpha untuk skala ini adalah 0.89. Locus of control Tuhan dinilai melalui skala enam item untuk mengukur pengaruh individu percaya bahwa Tuhan memiliki atas hidup mereka. Contoh item "Apa pun yang terjadi dalam hidup saya adalah kehendak Tuhan" (Wallston et al., 1999). Cronbach alpha untuk skala ini adalah 0.87 .

\section{HASIL DAN PEMBAHASAN}

\section{Analisis deskriptif}

Tabel 2 berikut ini menampilkan analisis deskriptif dan korelasi antar variable. Hasil analisis menunjukkan bahwa job insecurity secara positif berkorelasi dengan kecemasan $(r=0.496$, $p$ value < $0.01)$ dan negative dengan GLC $(r=0.11$, $p$ value $>0.05)$. Sementara itu, GLC terbukti memiliki korelasi negative dengan kecemasan $(r=-0.238$, $p$ value $<0.01)$. 
Tabel 2.

Deskripsi data dan korelasi antar variabel

\begin{tabular}{rlrrrrr}
\hline No & Variabel & Mean & \multicolumn{1}{l}{ S.D } & \multicolumn{1}{c}{1} & 2 & 3 \\
\hline 1 & Job insecurity & 3.52 & 0.87 & 1 & & \\
2 & Kecemasan & 3.12 & 0.88 & $.496^{* *}$ & 1 & \\
3 & God locus of control & 3.91 & 0.66 & -.011 & $-.238^{* *}$ & 1 \\
\hline
\end{tabular}

\section{Pengujian hipotesis}

Analisis data menggunakan teknik regresi hierarki moderasi menggunakan makro PROCESS versi 3.5 yang dikembangkan oleh Hayes (2017). Hasil analisis ditampilkan pada Tabel 3 menunjukkan bahwa hipotesis 1 yang menyatakan ada pengaruh positif job insecurity terhadap kecemasan terdukung $(\beta=$ 0.50 , $\mathrm{p}$ value $<0.01$ ). Selanjutnya hipotesis 2 yang menyatakan bahwa GLC memiliki pengaruh negative terhadap kecemasan juga berhasil didukung $(\beta=-0.61$, $p$ value $<0.01)$. Terakhir, interaksi antara job insecurity dan GLC juga terbukti signifikan $(\beta=-0.11$, p value $<0.05)$, mengindikasikan bahwa GLC terbukti memoderasi hubungan job insecurity dengan kecemasan.

Tabel 3.

Pengujian hipotesis (Makro Process model 1)

\begin{tabular}{|c|c|c|c|c|c|c|}
\hline & Coeff & $S E$ & $t$ & $p$ & $L L C I$ & $U L C I$ \\
\hline Job insecurity & 0.50 & 0.04 & 12.78 & 0.00 & 0.43 & 0.58 \\
\hline GLC & -0.61 & 0.05 & -6.04 & 0.00 & -0.42 & -0.21 \\
\hline Interaksi & -0.11 & 0.06 & -2.20 & 0.03 & -0.24 & -0.01 \\
\hline \multicolumn{7}{|c|}{ Conditional effects of the focal predictor at values of the moderator(s): } \\
\hline & & Effect & $S E$ & $p$-value & $L L C I$ & ULCI \\
\hline & GLC rendah & 0.597 & 0.056 & 0.00 & 0.47 & 0.71 \\
\hline & GLC mean & 0.4911 & 0.039 & 0.00 & 0.41 & 0.56 \\
\hline & GLC tinggi & 0.42 & 0.052 & 0.00 & 0.31 & 0.52 \\
\hline
\end{tabular}

Sumber: Data olahan, Proces Macro versi 3.5

\section{Pembahasan}

Tujuan dari penelitian ini adalah menguhi hubungan job insecurity dengan kecemasan karyawan sekaligus mengidentifikasi strategi koping yang mampu menahan efek negative job insecurity dengan menempatkan GLC. Hasilnya analisis memberikan pengetahuan yang relevan dengan literatur ilmiah yang terkait dengan studi ketidakamanan kerja, serta implikasi praktis untuk mengurangi efek fenomena ini pada tingkat kecemasan karyawan di tengah situasi pandemic COVID-19.

Sesuai dugaan, job insecurity terbukti secara positif mempengaruhi kecemasan karyawan, yang mengindikasikan bahwa ketidakamanan kerja yang dirasakan oleh karyawan. Penelitian menunjukkan bahwa karyawan yang merasakan ketidakamanan kerja terus-menerus merasa khawatir kehilangan pekerjaan dan pendapatan yang memicu kecemasan mereka ketika sedang di rumah. Tingkat kecemasan ini akan terus naik seiring dengan ketidakjelasan status dan pekerjaan seiring dengan belum selesainya pandemic COVID-19 yang terjadi sejak awal 2020. Studi ini mendukung temuan sebelumnya yang meberikan kesimpulan serupa bahwa job insecurity dapat bertindak sebagai predictor kecemasan karyawan (Cheung et al., 2018; Wang et al., 2019; Wilson et al., 2020).

Berikutnya, studi ini menemukan bahwa strategi yang paling relevan untuk mengatasi ketidakamanan kerja dan untuk mencegah tingginya tingkat kecemasan adalah melalui tingginya persepsi atas lokus kendali Tuhan. Efek moredasi GLC pada hubungan ketidakamanan kerja dan 
kecemasan seperti ditampilkan pada gambar 2 memperlihatkan bahwa efek ketidakamanan kerja terhadap kecemasan menurun seiring dengan tingginya GLC. Selain itu, GLC juga terbukti berpengaruh negative dan signifikan terhadap tingkat kecemasan yang menjadikan perannya sebagai kuasi moderator, yaitu dapat bertindak sebagai moderator dan variable bebas secara bersamaan.

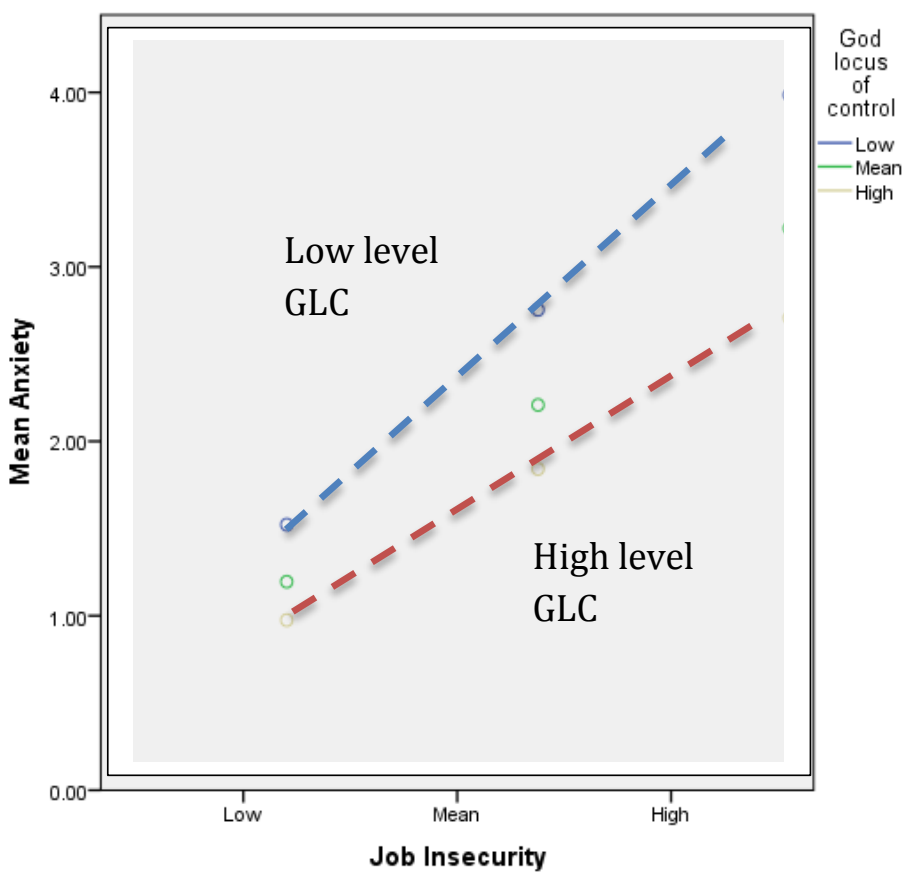

Gambar 2.

Hubungan job insecurity - kecemasan yang dimoderasi oleh GLC

\section{Implikasi Praktis / Teoritis}

Meskipun studi mengenai hubungan job insecurity dengan tingkat kecemasan sudah banyak dilakukan, namun menempatan GLC sebagai strategi koping masih belum pernah diteliti. Dengan demikian, studi ini memberikan wawasan baru pada peran GLC sebagai koping religius yang positif (Pargament et al., 2011) sehingga efeknya dapat mengurangi potensi kecemasan yang tinggi pada karyawan dalam stuasi yang tidak bisa dkontrol seperti pandemic sekarang.

Dari sisi praktis, hasil studi ini memberikan arah kebijakan kepada perusahaan untuk membuat kebijakan relevan yang dapat mendukung pengurangan tingakt ketidakamanan kerja dan kecemasan karyawan. Pertama, tidak dapat dipungkiri bahwa situasi COVID-19 telah menyebabkan penurunan pendapatan perusahaan yang mengakibatkan perlunya dilakukan penyesuaian pada biaya. Meski demikian, kebijakan untuk memberhentikan karyawan sebaiknya adalah keputusan akhir yang diambil. Mengurangi jam kerja dan memotong penghasilan karyawan untuk mengurangi beban biaya dapat dilakukan dengan terlebih dahulu berkomunikasi secara baik dengan karyawan untuk memperoleh solusi yang sama-sama tidak memberatkan kedua belah pihak. Kedua, perusahaan harus terus memberikan dukungan social untuk mengurangi efek negative ketidakamanan kerja melalui pertemuan-pertemuan online yang dapat dilakukan. 


\section{KESIMPULAN}

Stidi ini menyimpulkan bahwa ketidakamanan kerja memiliki pengaruh positif terhadap tingkat kecemasan karyawan. Lokus kendali Tuhan memiliki efek negative terhadap kecemasan dan juga bertindak sebagai kondisi batas untuk mengurangi efek ketidakamanan kerja terhadap kecemasan karyawan. Mengurangi persepsi ketidakamanan kerja tidak selalu memungkinkan selama krisis ekonomi. Oleh karena itu, strategi intervensi harus menargetkan mekanisme yang dapat mengurangi dampak negatif dari ketidakamanan kerja yang dirasakan. Temuan penelitian saat ini menyoroti peran penting God locus of control untuk meminimalkan stres akibat ketidakamanan kerja. Hasilnya memberikan wawasan penting ke dalam berbagai praktik sumber daya manusia untuk menurunkan tingkat kecemasan melalui dukungan sosial dan terus aktif berkomunikasi secara efektif.

\section{Keterbasan dan Saran}

Penelitian ini memiliki keterbatasan terutama pada jangkauan sampel yang hanya berada di Jakarta sehingga tidak memberikan gambaran tingka ketidakamanan kerja secara menyeluruh pada karyawan di Indonesia. Selain itu, studi ini tidak mengidentifikasi jenis dan sector perusahaan sehingga tidak dapat dipastikan sector mana yang paling terdampak pandemic COVID-19 sekarang ini. Berdasarkan keterbatasan tersebut maka studi berikutnya disarankan mempeluas area sampel dan secara khusus mengidentifikasi jenis atau bidang usaha perusahaan tempat responden bekerja sehingga dapat dibedakan tingkat ketidakamanan antar sector usaha.

\section{REFERENSI}

Ashford SJ, Lee C, Bobko P. (1989). Content, causes and consequences of job insecurity: a theorybased measure and substantive test. Acad Manag J. 32:803-829.

Bakker, A. B., \& Demerouti, E. (2007). The job demands-resources model: State of the art. Journal of managerial psychology. 22(3), https://doi.org/10.1108/02683940710733115

Cheung, F. Y. L., Wu, A. M., \& Ching Chi, L. (2019). Effect of job insecurity, anxiety and personal resources on job satisfaction among casino employees in macau: A moderated mediation analysis. Journal of Hospitality Marketing \& Management, 28(3), 379-396.

Darvishmotevali, M., Arasli, H., \& Kilic, H. (2017). Effect of job insecurity on frontline employee's performance: Looking through the lens of psychological strains and leverages. International Journal of Contemporary Hospitality Management.

De Witte, H. Arbeidsethos en jobonzekerheid: Meting en gevolgen voor welzijn, tevredenheid en inzetop het werk [Work ethic and job insecurity: Measurement and consequences for wellbeing, satisfactionand performance]. InVan groep naar gemeenschap [From Group to Community]; Bouwen, R., de Witte, K.,de Witte, H., Taillieu, T., Eds.; Garant: Leuven, Belgium, 2000; pp. 325-350.

De Cuyper, N., Schreurs, B., De Witte, H., \& Selenko, E. (2020). Impact of job insecurity on job performance introduction. Career Development International. 25(3), 221-228. https://doi.org/10.1108/CDI-06-2020-332

Gallie, D., Felstead, A., Green, F., \& Inanc, H. (2017). The hidden face of job insecurity. Work, employment and society, 31(1), 36-53.

Hobfoll, S. E., Freedy, J., Lane, C., \& Geller, P. (1990). Conservation of social resources: Social support resource theory. Journal of Social and Personal Relationships, 7(4), 465-478.

Lam, C.F.; Liang, J.; Ashford, S.J.; Lee, C. (2015). Job insecurity and organizational citizenship behavior: Exploringcurvilinear and moderated relationships. J. Appl. Psychol. 100, 499-510 
Lazarus, R. S., \& Folkman, S. (1984). Stress, appraisal, and coping. Springer publishing company.

Lim VKG. Job insecurity and its outcomes: moderating effects of work-based and nonwork-based social support. Hum Relat. 1996;49:171-19

Llosa, J. A., Menéndez-Espina, S., Agulló-Tomás, E., \& Rodríguez-Suárez, J. (2018). Job insecurity and mental health: a meta-analytical review of the consequences of precarious work in clinical disorders. anales de psicología.

Menéndez-Espina, S., Llosa, J. A., Agulló-Tomás, E., Rodríguez-Suárez, J., Sáiz-Villar, R., \& LahserasDíez, H. F. (2019). Job insecurity and mental health: the moderating role of coping strategies from a gender perspective. Frontiers in psychology, 10, 286.

Pargament, K. I. (2011). Spiritually integrated psychotherapy: Understanding and addressing the sacred. Guilford press.

Schumacher, D., Schreurs, B., Van Emmerik, H., \& De Witte, H. (2016). Explaining the relation between job insecurity and employee outcomes during organizational change: A multiple group comparison. Human Resource Management, 55(5), 809-827.

Schreurs, B.; Van Emmerik, H.; Notelaers, G.; De Witte, H. (2010). Job insecurity and employee health: The bufferingpotential of job control and job self-efficacy. Work Stress. 24, 56-72

Wang, W., Mather, K., \& Seifert, R. (2018). Job insecurity, employee anxiety, and commitment: The moderating role of collective trust in management. Journal of Trust Research, 8(2), 220-237.

Wilson, J. M., Lee, J., Fitzgerald, H. N., Oosterhoff, B., Sevi, B., \& Shook, N. J. (2020). Job insecurity and financial concern during the COVID-19 pandemic are associated with worse mental health. Journal of occupational and environmental medicine, 62(9), 686-691.

Zhang, Z., \& Chen, W. (2019). A systematic review of measures for psychological well-being in physical activity studies and identification of critical issues. Journal of affective disorders, $256,473-485$.

\section{PROFIL PENULIS}

Dr. Achmadi adalah dosen tetap di Sekolah Tinggi Ilmu Ekonomi Tunas Nusantara. Fokus penelitian saat ini adalah kepemimpinan, ketidakamanan kerja, dan marketing strategic. 
Jurnal Manajemen Strategi dan Aplikasi Bisnis, 3(2), 161-170 Achmadi. Job insecurity, kecemasan dan Gold locus of control

This page intention to blank... 